\title{
Present distribution of Potamopyrgus antipodarum (Gray, 1843) (Mollusca: Gastropoda) in the Slovak Republic
}

\author{
TOMÁš Č́EJKA ${ }^{1}$, Libor DVoŘÁK² \&Vladimír KoŠEL ${ }^{3}$ \\ ${ }^{1}$ Institute of Zoology, Slovak Academy of Sciences, Dúbravská cesta 9, SK-84506 Bratislava, Slovak Republic \\ e-mail: tomas.cejka@savba.sk \\ 2Šumava National Park Administration, Dept. of Science and Research, Sušická 399, CZ-34192 Kašperské Hory, Czech Republic, \\ e-mail: lib.dvorak@seznam.cz,liboR.dvorak@npsumava.cz \\ ${ }^{3}$ Faculty of Natural Sciences, Comenius University, Dept. of Zoology, Mlynská dolina, SK-84215 Bratislava, Slovak Republic, \\ e-mail:kosel@fns.uniba.sk
}

\begin{abstract}
ČEJKa T., DvořÁk L. \& Košel V., 2008: Present distribution of Potamopyrgus antipodarum (Gray, 1843) (Mollusca: Gastropoda) in the Slovak Republic. - Malacologica Bohemoslovaca, 7: 21-25. Online serial at $<$ http:// mollusca.sav.sk> 25-Feb-2008.

All published and known unpublished data on Potamopyrgus antipodarum (Gray, 1843) from the Slovak Republic are summarised. The Slovak distribution is restricted to the southern parts of the country close to the Danube, Morava, and Hron Rivers. Geographic and vertical distribution is described. The most of the localities are placed between 100 and $140 \mathrm{~m}$ a.s.l., the highest situated known record was in $277 \mathrm{~m}$ a.s.1. P. antipodarum inhabits slowly flowing rivers and different types of standing waters in Slovakia.
\end{abstract}

Key words: Potamopyrgus antipodarum, geographic distribution, ecology, Slovakia

\section{Introduction}

The aquatic snail Potamopyrgus antipodarum (Gray, 1843) was probably introduced for the first time to Europe from the New Zealand subregion as early as 1859. It was first recognised in Europe as Hydrobia jenkinsi by SMITH (1889) from Plumstead, Beeton and Erith, in the Thames estuary, England. Although there might have been earlier introductions, it is considered that the Thames introduction is the source of the population in Europe. This species is native to New Zealand from where it was introduced into Australia and Tasmania. It was introduced to Britain in drinking water barrels on ships from Australia (PONDER 1988). The snails were probably liberated while washing or filling water barrels or tanks and, because they can survive in brackish water, they could probably survive liberation into estuarine areas such as the Thames RiveR. This species can reproduce rapidly parthenogenetically. It thrives in freshwater and has become the most common freshwater gastropod in some European countries, e.g. Great Britain (HePpell 2008).

In the Slovak stretch of the Danube River it was found for the first time in 1986 by KoŠEL (1995), further records from the Danube River were published by ČEJKA (1994). Compared with other European countries its rate of spread around the Slovakia is moderate. Firstly along major rivers, then filling in the canals, ditches and smaller water bodies.

\section{Results}

Published data

Data are given as follows: number of the quadrate of the faunistic mapping grid (according to LISICKÝ 1991), site characteristics and references; "R." means river, "ch." means channel.

7770d: Senec, Senecké Jazero gravel pit, in the littoral woody debris, mass occurrence (ŠTEFFEK 2000), 7868a: Bratislava, Karloveské Rameno ch. (KoŠEl 1995, KošEl in KRNO et al. 1999), 8070a: Dobrohošt', main ch. of the Danube R., riprap stones (ČEJKa 1994, KošEl 1995, KošEl in KRno et al. 1999), 8070d: Bodíky, main ch. of the Danube R., riprap stones (ČEJKA 1994, Košel 1995, KošEl in KRno et al. 1999), Bodíky, side arm of the Danube R., eupotamal (KošEl 1995, KošEl in KRno et al. 1999), 8171c: Gabčíkovo, main ch. of the Danube R., riprap stones (KoŠEL 1995, KoŠEL in KRNO et al. 1999), 8272a: Kl'účovec, main ch. of the Danube R., riprap stones (KošEL 1995, KošEL in KRNO et al. 1999).

\section{Unpublished data}

Data are given as follows: coordinates according to WGS84 (Google Earth, Google teAm 2007), number of the quadrate of the faunistic mapping grid (according to LisickÝ 1991), nearest settlement, name of water body, site characteristics, elevation, absolute or relative abundance, date of collection, name of collector; "R." means river, "ch." means channel (river arm).

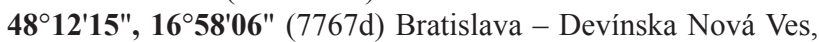
Morava R., main ch., 137 m a.s.1., 10 ind., 10 Nov 2005, Čejka \& Dvořák; 48³1'27", 1656'33" (7467d) Malé Leváre, Mo- 
rava R., main ch., 147 m a.s.1., 2 ind., 7 Sep 2006, Šporka \& Hamerlík; 48 ${ }^{\circ} \mathbf{1 4}^{\prime} \mathbf{0 4} ", \mathbf{1 7}^{\circ} \mathbf{1 2}^{\prime} 13^{\prime \prime}$ (7769c) Sv. Jur, ditch, $132 \mathrm{~m}$ a.s.l., mass occurrence, 9 Nov 2005, Čejka \& Dvořák; 4801'42", 17²1'48" (7972c) Dunajský Klátov, ditch, 110 m a.s.l., 5 ind., 5 Nov 2003, Čejka; $\mathbf{4 8}^{\circ} \mathbf{0 7}^{\prime} \mathbf{5 5}^{\prime \prime}, \mathbf{1 7}^{\circ} \mathbf{2 9}^{\prime 20}$ " (7870d) Jelka, Lesser Danube, eupotamal, 120 m a.s.l., 1 ind., 20 May 2005, Čejka; 48 09'38", 1705'13" (7868b) Bratislava - Horský Park, brook, 197 m a.s.l., mass occurrence, 8 Nov 2005, Čejka \& Dvořák; 48 01'37", 17¹2'18" (7969c) Bratislava-Čuňovo, Danube R., dextral seepage canal, on riprap stones 127 a.s.1., 2 ind., 28 Apr 1998, Čejka; $\mathbf{4 7}^{\circ} \mathbf{4 8} \mathbf{6 0 0}^{\prime \prime} \mathbf{1 8}^{\circ} \mathbf{4 4} \mathbf{2 0} "$ (8178c) Kamenica n. Hronom, Danube R., eupotamal, mud with admixed sand, $107 \mathrm{~m}$ a.s.1., 2 ind., 24 Oct 2007, Čejka; $\mathbf{4 8}^{\circ} \mathbf{3 3} \mathbf{4 8}^{\prime} \mathbf{\prime}^{\prime \prime} \mathbf{1 9}^{\circ} \mathbf{6}^{\prime} \mathbf{3 6 . 1 5 "}$ (7480b) Zvolen, Slatina R., estuary at the confluence with Hron R., gravel-cobblestone bottom, $277 \mathrm{~m}$ a.s.l., low abundant $(<1 \%), 19$ Apr 2002, Ščerbáková-Hrabinová; 4806'25", 1706'50" (7868d) Bratislava-Petržalka, Velký Draždiak gravel pit (bathing establishment in summer), littoral, sandy-gravel bottom, 132,5 m a.s.1., ca. 10 ind. $/ \mathrm{m}^{2}$, 15 Jun 2004, Dvořák; $\mathbf{4 8}^{\circ} \mathbf{0 7} \mathbf{7 2}^{\prime \prime}, \mathbf{1 7}^{\circ} \mathbf{1 0}^{\prime} \mathbf{2 5}$ (7868d) Bratislava-Vlčie Hrdlo district, Lesser Danube (arm of the Danube R.), eupotamal, $129 \mathrm{~m}$ a.s.1., 6 ind./1 hour visual search, 15 Jun 2007, Dvořák; 48 ${ }^{\circ} \mathbf{0 6}^{\prime} \mathbf{1 6}^{\prime \prime}, \mathbf{1 7}^{\circ} \mathbf{0 8} \mathbf{2 6}^{\prime}$ " (7868c) Bratislava-Vlčie Hrdlo, Danube R. (river km 1863), eupotamal, ripal, no macrophytes, contaminated by Slovnaft rafinery, slow flow (partially lenitic), 20-30 cm muddy sediment with admixed sand. Mean flow $1612 \mathrm{~m}^{3} . \mathrm{s}^{-1} ; 135 \mathrm{~m}$ a.s.1., 3 ind., 26.11.1998, Elexová; 47²9'13", 18 ${ }^{\circ} 48^{\prime} 53 "$ (8178c) Chl'aba, Danube R., 5 km downstream from Hron and Danube confluence, main ch., eupotamal, littoral zone, cobble bottom, no macrophytes, mean flow 1898 $\mathrm{m}^{3} . \mathrm{s}^{-1}$, mean water level $152 \mathrm{~cm}, 103 \mathrm{~m}$ a.s.1., 2 ind., 7 Oct 1997; Elexová; 4745'38", $\mathbf{1 8}^{\circ} 08^{\prime} 35^{\prime \prime}$ (8274b) Komárno, Váh R. estuary, muddy sediment with admixed sand, several stones, mean flow $85 \mathrm{~m}^{3} . \mathrm{s}^{-1}$, 110,7 m a.s.1., 16 Sep 1997, Elexová; 4753'01", 18 ${ }^{\circ} 5^{\prime} 49^{\prime \prime}$ (8178b) Salka, Ipel' R., cobble-gravel bottom, several bunches of submersed macrophytes, flow fluctuates, $110 \mathrm{~m}$ a.s.l., 2 ind., 7 Dec 1998, Elexová; 4752'30", 17²9'13" (8171a) Baka,
Danube R. (R. km 1823.5, Bačianske Rameno ch.), parapotamal, littoral, riprap stones, 118 m a.s.l., 3 ind. h $^{-1}, 22$ Nov 1989, Košel; 4755'26", 17²6'41" (8070d) Bodíky, Danube R. (R. km 1823.5, Bodícke Rameno ch.), eupotamal, littoral, riprap stones, $118 \mathrm{~m}$ a.s.1., 3 ind.h ${ }^{-1}, 2-95$ ind. $\mathrm{m}^{-2}, 22$ Aug 2001, 11 Oct 2001, 18 Jun 2003, 16 Jul 2003, 11 Sep 2003, 3 Jun 2004, 28 Sep 2004, 1 Jun 2005, 10 Aug 2005, 14 Jun 2006, 31 Jul 2006, 29 Sep 2006, 6 Jun 2007, 9 Aug 2007, Košel; 48 ${ }^{\circ} 11^{\prime} 19.59 ", 1^{\circ} \mathbf{1 1}^{\prime 24} 4^{\prime \prime}$ (7869a) Bratislava - Zlaté Piesky, gravel pit (bathing establishment in summer), littoral, $128 \mathrm{~m}$ a.s.l., 42 ind.h ${ }^{-1}$ (91.3\%, eudominant), 17-24 ind.m ${ }^{-2}, 22$ Aug 2001, 11.10.2001, Košel; $\mathbf{4 8}^{\circ} \mathbf{0 3}{ }^{\prime}{ }^{\prime}$ ", 17 ${ }^{\circ} 9^{\prime} 50^{\prime \prime}$ (7968b) Bratislava - Rusovce, main ch. of the Danube R. (R. km 1858), ripal, riprap stones, $107 \mathrm{~m}$ a.s.l., 3 ind. $\mathrm{m}^{-2}$ (91.3 \%, eudominant), 17-24 ind.m ${ }^{-2}, 22$ Aug 2001, 11.10.2001, Košel; 47 59'14", 17 ${ }^{\circ} \mathbf{2 0}^{\prime} 37^{\prime \prime}$ (8070a) Dobrohošt', main ch. of the Danube R. (R. km 1840.5), ripal, riprap stones, $122,4 \mathrm{~m}$ a.s.1., 17-24 ind.m ${ }^{-2}, 28$ Sep 1995-10 Nov 2002, Košel; 4759'32", 17' 21'04" (8070a) Dobrohošt', dextral seepage canal of the Gabčíkovo hydraulic structures (R. $\mathrm{km} \mathrm{1840),} \mathrm{littoral,} \mathrm{stones,} 123 \mathrm{~m}$ a.s.l., 10 Jun 1996, Šípoš; 47²57'41", 17³5'28" (8071a) Dunajská Streda, Vojka-Mliečany ditch, cobbles in a littoral zone $116 \mathrm{~m}$ a.s.l., 12 Aug 1998, Š́́poš; $\mathbf{4 7}^{\circ} \mathbf{5 1} \mathbf{1}^{\prime} \mathbf{6} \mathbf{6}^{\prime \prime} \mathbf{1 7}^{\circ} \mathbf{3 1} \mathbf{4 1 . 5 "}$ (8171a) Gabčíkovo, main ch. of the Danube R. (R. km 1819,7), ripal, riprap stones, 114 m a.s.l., 5-137 ind.m ${ }^{-2}$, 12 Aug 1997-28 Sep 2004, Košel; $4^{\circ} 01 ' 57^{\prime \prime}, 1^{\circ} 14^{\prime} 51 "$ (7969c) Hamuliakovo, reservoir of the Gabčíkovo waterworks, mud with admixed sand, 131,5 $\mathrm{m}$ a.s.1., 10 ind. ${ }^{-2}, 16$ Oct 1995-13 Sep 2001, Nagy; $\mathbf{4 8}^{\circ} \mathbf{0 2} \mathbf{4 9}^{\prime \prime}, \mathbf{1 7}^{\circ} \mathbf{1 4}^{\prime} \mathbf{1 6}^{\prime \prime}$ (7969a) Kalinkovo, reservoir of the Gabčíkovo waterworks, muddy substrate with admixed sand, $132 \mathrm{~m}$ a.s.1., 2 ind. $\mathrm{m}^{-2}, 26$ Sep 1995, Śípoš; $\mathbf{4 7}^{\circ} \mathbf{4 7}^{\prime 2} \mathbf{2 1}$ ", $\mathbf{1 7}^{\circ} \mathbf{3 9} \mathbf{4 7}^{\prime}$ " (8272a) Klúčovec, main ch. of the Danube R., ripal with riprap stones, $110 \mathrm{~m}$ a.s.1., 2-27

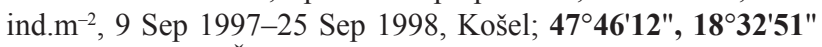
(8277a) Mužla - Čenkov, main ch. of the Danube R., ripal with riprap stones, $107 \mathrm{~m}$ a.s.l., 6 ind. $\mathrm{m}^{-2}$, 22 Aug 1989, 6 ind.m ${ }^{-2}, 1$ Oct 1992, Košel; 48 $\mathbf{5 1}^{\prime} \mathbf{3 7 . 6} \mathbf{6}^{\prime \prime} \mathbf{1 7}^{\circ} \mathbf{1 5}^{\prime} \mathbf{4} 7.6^{\prime \prime}$ (7169c) Skalica, littoral zone of the Sudoměřický Potok brook, $3 \mathrm{~km}$ from confluence

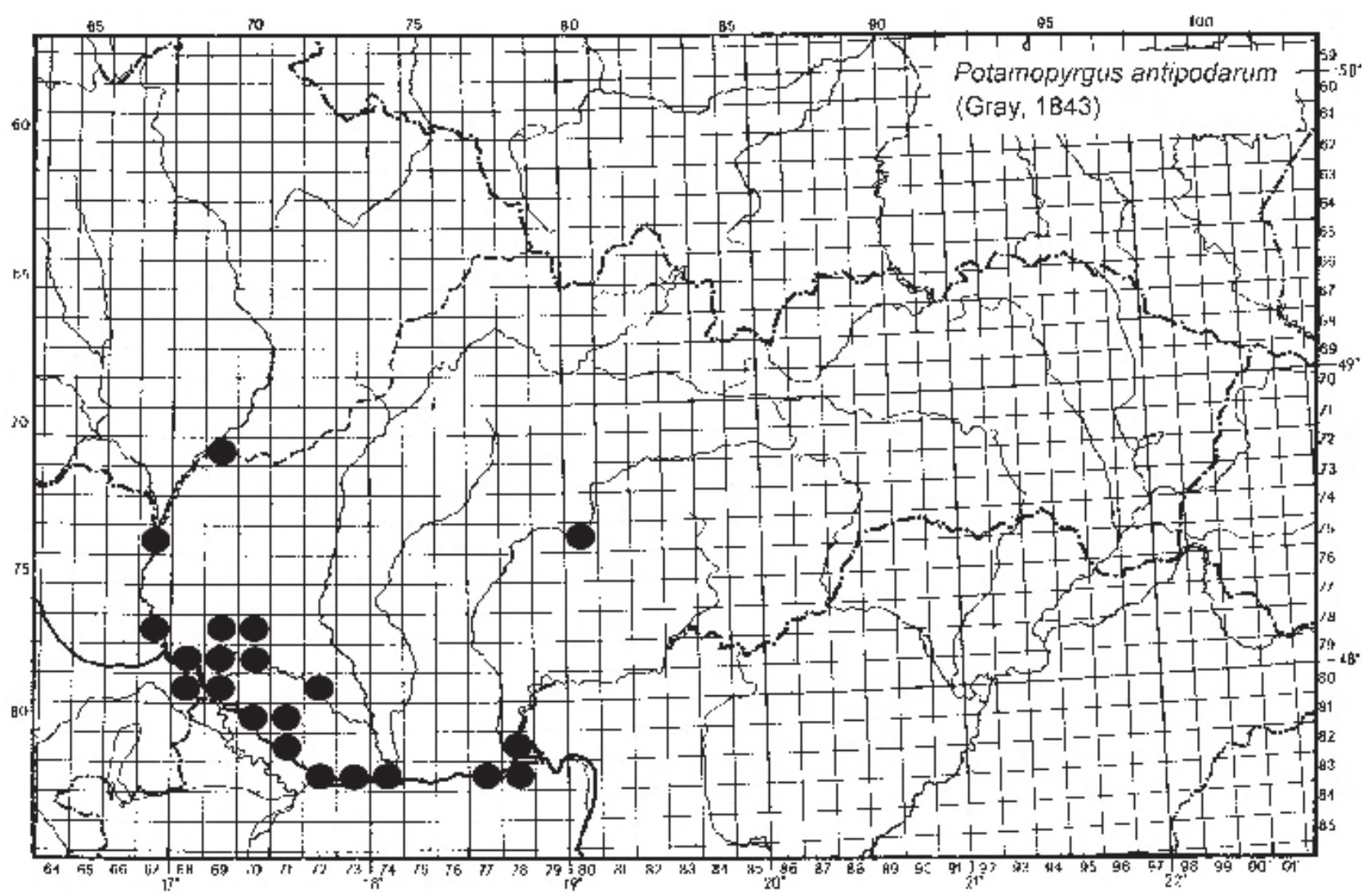

Fig. 1. The present distribution of Potamopyrgus antipodarum in the Slovak Republic. 
with Radějovka brook, 224 m a.s.l., 3 ind., 2 Oct 2002, Šípoš; 48 $^{\circ} 01^{\prime} 11^{\prime \prime}, 1^{\circ} \mathbf{1 7}^{\prime} \mathbf{1 5}^{\prime \prime}$ (7969d) Šamorín, reservoir of the Gabčíkovo waterworks, mud with admixed sand, R.km 1845, 131,5 m a.s.1., 2 ind. ${ }^{-2}, 14$ Nov 1995, Šípoš; $\mathbf{4 7}^{\circ} \mathbf{4 7}^{\prime} \mathbf{5 3}$ ", $\mathbf{1 8}^{\circ} \mathbf{4 3} \mathbf{4 1}^{\prime}$ (8278a) Śtúrovo, main ch. of the Danube R., R.km 1718,4, riprap stones, 105 m a.s.l., 2 ind.m ${ }^{-2}$, 29 Sep 1991, Košel; 4756'27", 17'26'22" (8070a) Šulany, Danube R. - Šulianske Rameno ch., parapotamal, riprap stones, 119 m a.s.1., 12 ind.m ${ }^{-2}, 22$ Sep 1992, Košel; 47 58'24", 17²8'33" (8070a) Šul'any, Dobrohošt'-Vojka-Kračany ditch, littoral, gravel-sandy bottom $121 \mathrm{~m}$ a.s.1., 1 ind.

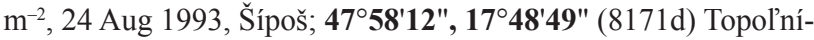
ky, Lesser Danube, Topol'nícke Rameno arm, parapotamal, riprap stones, 113,6 m a.s.l., 9 ind.h ${ }^{-1}, 1$ Sep 1991, Košel; $\mathbf{4 7}^{\circ} \mathbf{5 8}^{\prime} \mathbf{0 0}$ ", 17'22'07" (8070a) Vojka nad Dunajom, main channel of the Dunaj R., R.km 1838, eupotamal, riprap stones, $122 \mathrm{~m}$ a.s.1., 11 ind. m $^{-2}, 1$ Sep 1991, Košel; $\mathbf{4 7}^{\circ} \mathbf{5 8}^{\prime} \mathbf{4 2}^{\prime \prime}, \mathbf{1 7}^{\circ} \mathbf{2 5}^{\prime} \mathbf{0 5}$ " (8070a) Vojka nad Dunajom, Dobrohošt'-Vojka-Kračany ditch (R.km 2.0-5.0), littoral, 123 m a.s.1., 11 ind. $\mathrm{m}^{-2}$, 24 Aug 1993, Šípoš; $\mathbf{4 7}^{\circ} \mathbf{4 5} \mathbf{2 5}$ ", 1758'41" (8273b) Zlatná n. Ostrove, main ch. of the Danube R., ripal, riprap stones, 108 m a.s.l., 3 ind. h ${ }^{-1}$, 29 Oct 1991, Košel. For distribution in Slovakia see at Fig. 1.

\section{Distribution in some European and west Asian coun- tries}

P. antipodarum is a common species in England, Scotland, and Ireland (KERNEY 1999). The situation is similar on the West European seacoast - the species is common in the Netherlands, mainly along the seacoast (GITTENBERGER et al. 1998), Belgium (AdAm 1960), France (FAlKNer et al. 2002) and in Germany, where it is a widespread species, but is the most common in northern states (GLÖER 2002, Glöer \& Meier-Brook 2003). Close to Central Europe, $P$. antipodarum is widespread in Switzerland (except for the mountains and the South (RÜETSCHI, pers. comm., CSCF 2008) and all federal states of Austria (Sattmann \& MiLDNER 1998).

It is a relatively rare species in North Europe and it is restricted to the southern parts only. The published data comprise e.g. South Norway (ØKLAND 1990), West Sweden (Nielsson et al. 1998), Denmark (Mandahl-Barth 1949), Finnish coastline (VALOVIRTA 1987) or Kaliningrad Area of Russia (Kantor \& Sysoev 2005). There is only one record of Potamopyrgus antipodarum in Belarus. It was found by PolischuK et al. (1976) in the wetlands of the lower courses of the Pripyat River (sometimes in 'high densities').

The distribution in Central Europe towards east is more fractional. $P$. antipodarum is relatively common in the Czech Republic, mainly in Northwest Bohemia (BERAN 2002, 2006). In Poland, the distribution comprises the seacost and lowland areas of the whole country (PIECHOCKI 1979). In Hungary, the distribution is restricted to the Danube River and Balaton Lake, the single record is known from the north (Frank et al. 1990, Pintér \& SuARA 2004). The only data from Ukraine are known from several bays of the Black Sea (Ukraine) (KAntor \& Sysoev 2005).

The species is probably rare in South Europe, except Italy, where it is common and widespread (Cianfanelli 2007) and Spain (GLÖER, pers. comm.). The only locality is known from Romania, where $P$. antipodarum was found in the Cerna River, near Serbian border (SIRBU 2004). GLÖER (pers. comm.) examined many mollusc samples from Montenegro and South Serbia (S of Beograd) and a few from Greece and Turkey (also from Iraq and Iran), all without $P$. antipodarum. On the other hand, GLÖER (pers. comm.) found this species in Lebanon. The occurrence of $P$. antipodarum well corresponds with the situation in surrounding countries: the species occurrence seems to be fractional towards the east.

\section{Biology and ecology}

Potamopyrgus antipodarum occurs at high densities in a wide range of freshwater habitats throughout New Zealand. $P$. antipodarum is a nocturnal grazer, feeding on plant and animal detritus, epiphytic and periphytic algae, sediments and diatoms (BROEKHUIZEN et al. 2001, JAMES et al. 2000, Kelly \& Hawes 2005, Parkyn et al. 2005, ZARANKo et al. 1997). The snail tolerates siltation, thrives in disturbed watersheds, and benefits from high nutrient flows allowing for filamentous green algae growth. It occurs amongst macrophytes and prefers littoral zones in lakes or slow streams with silt and organic matter substrates, but tolerates high flow environments where it can burrow into the sediment (ZARANKO et al. 1997, COLLIER et al. 1998, Holomuzki \& BigGs 1999, HolomuzKi \& BigGs 2000, Negovetic \& Jokela 2000, Richards et al. 2001, Weatherhead \& James 2001, Death et al. 2003, Schreiber et al. 2003, Suren 2005). The snail reaches high densities, e.g. in the Great Lakes, North America, it reaches densities as high as $5,600 \mathrm{~m}^{-2}$ and is found at depths of 4-45 m on a silt and sand substrate (ZARANKO et al. 1997, LEVRI et al. 2007). P. antipodarum is ovoviviparous and parthenogenic. The snail produces $\sim 230$ young per year. Reproduction occurs in spring and summer, and the life cycle is annual (Zaranko et al. 1997, Schreiber et al. 1998, Lively \& Jokela 2002, Gerard et al. 2003, Hall et al. 2003). This species is euryhaline, establishing populations in fresh and brackish water. The optimal salinity is probably near or below 5 ppt, but $P$. antipodarum is capable of feeding, growing, and reproducing at salinities of $0-15 \mathrm{ppt}$ and can tolerate 30-35 ppt for short periods of time (JACOBSEN \& Forbes 1997, ZARANKo et al. 1997, LePpäKOSKI \& OlENIN 2000, Costil et al. 2001, Gerard et al. 2003). It tolerates temperatures of $0-34^{\circ} \mathrm{C}$ (ZARANKo et al. 1997 , Cox \&

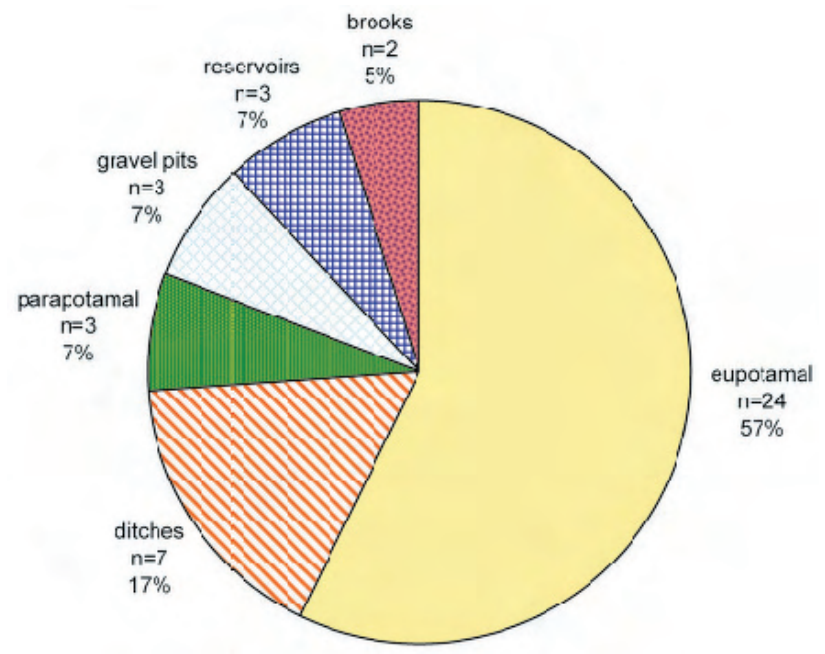

Fig. 2. The distribution of Potamopyrgus antipodarum in different freshwater habitats in Slovakia. 


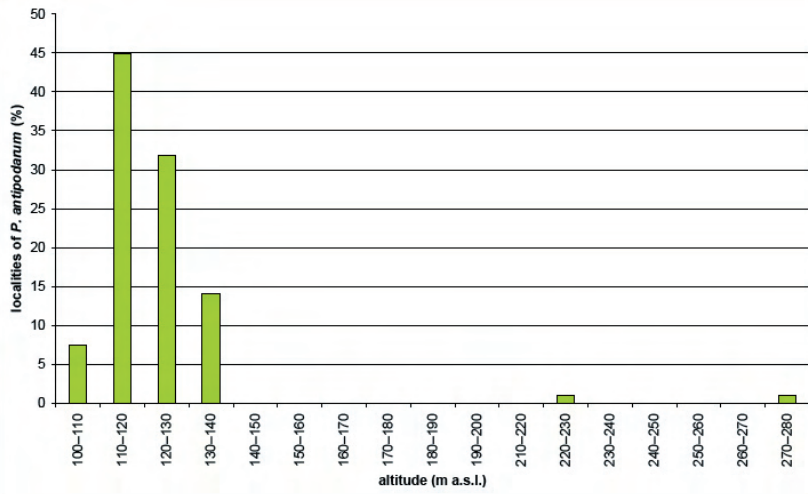

Fig. 3. Frequency of occurrences of the snail Potamopyrgus antipodarum in different altitudes in the territory of Slovakia.

Rutherford 2000). P. antipodarum can survive passage through the guts of fish and birds and may be transported by these animals (AAMIO \& BORNSDORFF 1997).

In Slovakia, it was found in rivers - the highest proportion $(57 \%)$ of the published and unpublished data listed in this paper belong to eupotamal water bodies, it is also common in ditches $(17 \%)$. The distribution of Potamopyrgus antipodarum in different freshwater habitats in Slovakia see in Fig. 2.

Concerning the vertical distribution of $P$. antipodarum in Slovakia, most of Slovak records were in the altitude of 110-120 m a.s.l. (see Fig. 3).

\section{Acknowledgements}

Authors wish to thank Peter Glöer (Germany), Peter Reischütz (Austria), and Maxim Vinarski (Russia) for their help with excerption of the published and unpublished sources. We are obligated to Michal Horsák (Czech Republic) for improving the English. The work was partly supported by grant of VEGA No. 1/4353/07.

\section{References}

Aamio K. \& BornsdorfF E., 1997: Passing the gut of juvenile flounder Platichthys flesus (L.) - differential survival of zoobenthic prey species. - Marine Biology, 129: 11-14.

Adam W., 1960: Faune de Belgique. Mollusques, 1. Mollusques terrestres et dulcicoles. - Inst. R. Sci. nat. Belgique, Bruxelles, 402 pp. +4 Tables.

Beran L., 2002: Vodní měkkýši České republiky - rozšíření a jeho změny, stanoviště, šiřrení, ohrožení a ochrana, červený seznam [Aquatic molluscs of the Czech Republic - distribution and its changes, habitats, dispersal, threat and protection, Red List)]. - Sborník Př́rodovědného klubu v Uh. Hradišti, Supplementum 10, $258 \mathrm{pp}$.

Beran L., 2006: Potamopyrgus antipodarum (Gray, 1843) - písečník novozélandský [New zealend Mud Snail]. - In: Nepůvodní druhy fauny a flóry České republiky, MLíKovskÝ J. \& STÝblo P. (eds) ČSOP, Praha, pp. 221-222.

Broekhuizen N., Parkyn S. \& Miller D., 2001: Fine sediment effects on feeding and growth in the invertebrate grazer Potamopyrgus antipodarum (Gastropoda, Hydrobiidae) and Deleatidium sp. (Ephemeroptera, Letpophlebiidae). -Hydrobiologia, 457(1-3): 125-132.

Cianfanelli S., Lori E. \& Bodon M., 2007: Non-indigenous freshwater molluscs and their distribution in Italy. - In: Biological invaders in inland waters: Profiles, distribution, and threats, GHERARDi F. (ed.) Springer Netherlands, pp. 103-121.
Collier K. J., Wilcock R. J. \& Meredith A. S., 1998: Influence of substrate type and physico-chemical conditions on macroinvertebrate faunas and biotic indices in some lowland Waikato, New Zealand, streams. - New Zealand Journal of Marine and Freshwater Research, 32: 1-19.

Costil K., Dussart G.B.J. \& Daquzan J., 2001: Biodiversity of aquatic gastropods in the Mont St-Michel basin (France) in relation to salinity and drying of habitats. - Biodiversity and Conservation, 10: 1-18.

Cox T.J. \& Rutherford J.C., 2000: Thermal tolerances of two stream invertebrates exposed to diurnally varying temperature. - New Zealand Journal of Marine and Freshwater Research, 34: 203-208.

CSCF, 2008: Centre Suisse de Cartographie de la Faune, Neuchâtel, Suisse (online, ver. 29-Jan-2008) http://www.cscf. ch

ČEJKA T., 1994: First record of the New Zealand mollusc Potamopyrgus antipodarum (Gray, 1843), (Gastropoda, Hydrobiidae) from the Slovak section of the Dunaj river. - Biologia, Bratislava, 49: 657-658.

Death R. G., Baillie B. \& Fransen P., 2003: Effect of Pinus radiata logging on stream invertebrate communities in Hawke's Bay, New Zealand. - New Zealand Journal of Marine and Freshwater Research, 37: 507-520.

FALKNer G., Ripken T.E.J. \& FALKNER M., 2002: Mollusques continentaux de France. Liste de référence anotée et bibliographie. - Museum National d'Histoire Naturelle, Paris, 350 pp.

Frank C., Jungbluth J \& Richnovszky A., 1990: Die Mollusken der Donau vom Schwarzwald bis zum Schwarzen Meer. - Akaprint, Budapest, 142 pp.

Gerard C., Blanc A. \& Costil K., 2003: Potamopyrgus antipodarum (Mollusca: Hydrobiidae) in continental aquatic gastropod communities: impact of salinity and trematode parasitism. - Hydrobiologia, 493: 167-172.

Gittenberger E., Janssen A.W., Kuijper W.J., Kuiper J.G.J., MeIJeR T., VAN deR Velde G. \& de Fries J.N., 1998: De Nederlandse Zoetwatermollusken. Recente en fossiele Weekdieren uit Zoet en Brak Water. - In: Nederlandse fauna 2, GitTenBerger E. \& JansSEN A.W. (eds) Nationaal Natuurhistorisch Museum Naturalis, KNNV Uitgeverij \& EIS-Nederland, Leiden, 288 pp.

GLÖER P., 2002: Süßwassergastropoden Nord- und Mitteleuropas. - ConchBooks, Hackenheim, 327 pp.

GlÖER P. \& MeIER-Brook C., 2003: Süsswassermollusken. - Deutschen Jungendbund für Naturbeobachtung, Hamburg, $134 \mathrm{pp}$.

Google TEAM, 2007: Google Earth ${ }^{\mathrm{TM}}$ mapping service (online, ver. 4.0.2737) http://earth.google.com/

Hall R.O. jr., TanK J.L. \& Dybdahl M.F., 2003: Exotic snails dominate nitrogen and carbon cycling in a highly productive stream. - Frontiers in Ecology and the Environment, 1 (8): 407-411.

Heppell D., 2008: Potamopyrgus antipodarum. Joint Nature Conservation Commitee - JNCC adviser to Government (online, ver. 21-Jan-2008) http://www.jncc.gov.uk/

Holomuzki J.R. \& Biggs B.J.F., 1999: Distributional responses to flow disturbance by a stream-dwelling snail. - Oikos, 87 (1): 36-47.

Holomuzki J.R. \& Biggs B.J.F., 2000: Taxon-specific responses to high-flow disturbances in streams: implications for population persistence. - Journal of the North American Benthological Society, 19 (4): 670-679.

JACOBSEN R. \& FoRBES V.E., 1997: Clonal variation in life-history traits and feeding rates in the gastropod, Potamopyrgus antipodarum: performance across a salinity gradient. - Functional Ecology 11 (2): 260-267.

James M.R., Hawes I. \& Weatherhead M., 2000: Removal of settled sediments and periphyton from macrophytes by grazing 
invertebrates in the littoral zone of a large oligotrophic lake. - Freshwater Biology 44 (2): 311-326.

Kantor, Yu.I. \& Sysoev, A.V. 2005. Katalog mollyuskov Rossii sopredel'nykh stran [Catalogue of Mollusks of Russia and adjacent regions]. - KMK Scientific Press Ltd., Moskva, 627 pp.

Kelly D.J. \& Hawes I., 2005: Effects of invasive macrophytes on littoral-zone productivity and foodweb dynamics in a New Zealand high-country lake. - Journal of the North American Benthological Society, 24 (2): 300-320.

Kerney M., 1999: Atlas of the Land and Freshwater Molluscs of Britain and Ireland. - Harley Books, Colchester, 261 pp.

KošEL V., 1995: Ripálny makrozoobentos Dunaja pred a po sprevádzkovaní vodného diela Gabčíkovo [Ripal macrozoobentos in the Danube River before and after putting hydraulic power plant into operation]. - In: Výsledky a skúsenosti z monitorovania bioty územia ovplyvneného vodným dielom Gabčíkovo, LISICKÝ M.J. \& SvobodovÁ A. (eds) zborník z konferencie, Ústav zoológie a ekosozológie SAV, Bratislava: 123-131.

Krno I., Šporka F., Matis D., Tirjaková E., Halgoš J, Košel V., BulánKová E. \& IllÉŠová D., 1999: Development of zoobenthos in the Slovak Danube inundation area after the Gabčíkovo hydropower structures began operating. - In: Gabčíkovo part of the hydroelectric power project environmental impact review (evaluation based on six year monitoring), MuchA I. (ed.) Ground Water Co., Ltd., Bratislava: 175-200.

LeppäKoski E. \& Olenin S., 2000: Non-native species and rates of spread: lessons from the brackish Baltic Sea. - Biological Invasions, 2 (2): 151-163.

Levri E.P., Kelly A.A. \& Love E., 2007: The invasive New Zealand mud snail (Potamopyrgus antipodarum) in Lake Erie. - Journal of Great Lakes Research, 33: 1-6.

LisICKÝ, M.J., 1991: Mollusca Slovenska. [Mollusca of Slovakia]. - Veda, Bratislava, $341 \mathrm{pp}$.

Lively C.M. \& Jokela J., 2002: Temporal and spatial distribution of parasites and sex in a freshwater snail. - Evolutionary Ecology Research, 4 (2): 219-226.

Mandahl-Barth G., 1949: Danmarks Fauna 54. Bløddyr, Ferskvandsbløddyr. - København, 249 pp.

Negovetic S. \& Jokela J., 2000: Food choice behaviour may promote habitat specificity in mixed populations of clonal and sexual Potamopyrgus antipodarum. - Experimental Ecology, 60 (4): 435-441.

Nitsson C., Ericsson U., Medin M. \& Sundberg I., 1998: Sötvattensnäckor I södra Sverige - en jämförelse med 1940-talet. - Snesk Miljöövervakning. - Raport 4903, Stockholm, 78 pp.

ØKLAND J., 1990: Lakes and snails: Environment and Gastropoda in 1,500 Norwegian lakes, ponds and rivers. - Universal Book Services/DR.W. Backhuys, Oegstgeest, Nederland, 515 pp.

Parkyn S.M., Quinn J.M., Cox T.J. \& Broekhuizen N., 2005 Pathways of $\mathrm{N}$ and $\mathrm{C}$ uptake and transfer in stream food webs: an isotope enrichment experiment. - Journal of the North American Benthological Society, 24 (4): 955-975.

Piechocki A., 1979: Mięczaki (Mollusca). Ślimaki (Gastropoda).
Fauna Słodkowodna Polski 7. [Molluscs (Mollusca). Snails (Gastropoda). Freshwater fauna of Poland 7.]. - PWN, Warszawa, Poznań, 187 pp.

PINTÉR L. \& SuARA R., 2004: Magyarországi puhatestűek katalógusa. Hazai malakológusok gyüjtései alapján [Catalogue of Hungarian Mollusca. Records of Hungarian malacologists]. - Magyar Természettudományi Múzeum, Budapest, 547 pp.

Polischuk V.V., Travyanko V.S. \& Stavinskaya A.M., 1976: Aquatic fauna of Pripyat Poles'e and its peculiarities. - In: Biological background of the exploitation, restoration, and conservation of Belarusian animal world, abstracts of the 4th zoological conference of Belarusian SSR, Minsk: 27-28.

Ponder W.F., 1988: Potamopyrgus antipodarum: a molluscan coloniser of Europe and Australia. - Journal of Molluscan Studies, 54: 271-285.

Richards D.C., Cazier L.D. \& Lester G.T., 2001: Spatial distribution of three snail species, including the invader Potamopyrgus antipodarum, in a freshwater spring. - Western North American Naturalist, 61 (3): 375-380.

SatTMann H. \& Mildner P., 1998: Nachweise der Neuseeländischen Zwergdeckelschnecke Potamopyrgus antipodarum (Gray, 1843) im Burgenland und in der Steiermark. - Nachr.bl. erste Vorarlb. malak. Ges., 6: 1.

Schreiber E.S.G., Glaister A., Quinn G.P. \& Lake P.S., 1998: Life history and population dynamics of the exotic snail Potamopyrgus antipodarum (Prosobranchia: Hydrobiidae) in Lake Purrumbete, Victoria, Australia. - Marine and Freshwater Research, 49 (1): 73-78.

SIRBU I., 2004: Comunitățile de moluşte acvatice din Dunăre sectorul Baziaş [Freshwater mollusc communities in the Danube River in the Baziaş section]. - Orsova (Banat.) Muzeul Brukenthal, Studii şi Comunicări, Ştiințele Naturii, 29: 107-134.

Sмiтн E.A., 1889: Notes on British Hydrobiidae with a description of a supposed new species. - Journal of Conchology, 6: $142-145$.

SuREN A.M., 2005: Effects of deposited sediment on patch selection by two grazing stream invertebrates. - Hydrobiologia, 549 (1): 205-218.

Šteffek J., 2000: Nový nález Potamopyrgus antipodarum (Hydrobiidae, Gastropoda, Mollusca) na Slovensku [New record of Potamopyrgus antipodarum (Hydrobiidae, Gastropoda, Mollusca) in the Slovakia]. - Folia faunistica Slovaca, 5: 61-62.

Turner H., Kuiper J.G.J., Thew N., Bernasconi R., RÜETSChi J., Wüthrich M. \& Gosteli M., 1998: Atlas der Mollusken der Schweiz und Liechtensteins. - Fauna Helvetica 2, Neuchâtel, $527 \mathrm{pp}$.

VAlovirTa I., 1987: Vesikotilot. - In: Suomen eläimet 5, HuhtA V. (ed.) Weilin \& Göös, Esbo, pp. 152-159.

WeATHERHEAD M.A. \& James M.R., 2001: Distribution of macroinvertebrates in relation to physical and biological variables in the littoral zone of nine New Zealand lakes. - Hydrobiologia, 462: 115-129. 